\title{
Pleurospermum austriacum (Apiaceae) - nowy górski gatunek we florze Wyżyny Częstochowskiej
}

Pleurospermum austriacum (L.) Hoffm. (żebrowiec górski) jest gatunkiem górskim, środkowoeuropejskim (ZAJĄC \& ZAJĄC 2009). Jego stanowiska koncentrują się w Alpach, Karpatach, Sudetach oraz na obszarach wyżynnych Europy Środkowej (Meusel i in. 1978). W Polsce, oprócz Karpat i Sudetów, występuje na rozproszonych, reliktowych stanowiskach na Wyżynie Krakowsko-Częstochowskiej, Wyżynie Małopolskiej, Wyżynie Lubelskiej oraz Pomorzu Wschodnim (SZAFER 1930; Środoń 1970; ZAJĄC 1996).

W maju 2018 r. Pleurospermum austriacum został znaleziony w masywie Popielowej Góry w paśmie Skał Kroczyckich na Wyżynie Częstochowskiej, około 30 metrów od szczytu skałki Bogdanka, na wysokości 375 m n.p.m. Populacja liczyła 47 roślin, w tym 11 kwitnących (czerwiec 2018 r.) i owocujących (sierpień 2018 r.) skupionych na powierzchni około $25 \mathrm{~m}^{2}$ na płaskiej, lekko pochylonej ku zachodowi skale, w płacie żyznej buczyny sudeckiej Dentario enneaphyllidis-Fagetum (Ryc. 1). W czerwcu 2019 r. stwierdziłem obecność 55 wyłącznie płonnych roślin, z których większość wykazywała oznaki zwiędnięcia. Brak roślin kwitnących był prawdopodobnie spowodowany suszą trwającą od połowy maja do końca czerwca, tj. w okresie rozwoju pędów kwiatostanowych i kwitnienia żebrowca górskiego. W czerwcu 2020 r., po wyjątkowo ciepłej i bezśnieżnej zimie, obserwowałem 52 rośliny, w tym tylko dwie kwitnące.

Stanowisko Pleurospermum austriacum w paśmie Skał Kroczyckich jest pierwszym na Wyżynie Częstochowskiej. Najbliższe stanowiska gatunku, znajdujące się w Ojcowskim Parku Narodowym (leg. W. Jastrzębowski cf. RostafiŃski 1872) oraz w rezerwacie Kępie na Wyżynie Miechowskiej (leg. B. Pawłowski 1950, KRAM) zostały uznane za wymarłe (Michalik 1978; Bróż i in. 2006). Próba odnalezienia P. austriacum w Myślachowicach koło Trzebini na granicy Wyżyny Krakowsko-Częstochowskiej i Wyżyny Śląskiej (leg. A. Sendek 1973, KRA) (CeliŃsKi i in. 1978-1979), którą podjąłem w czerwcu 2019 r., zakończyła się niepowodzeniem.

Występowanie Pleurospermum austriacum na Wyżynie Małopolskiej ma charakter reliktowy i zostało udokumentowane materiałem kopalnym pochodzącym ze zlodowacenia północnopolskiego (MAMAKOWA \& ŚRODOŃ 1977). Przystosowanie gatunku do życia w warunkach klimatu zimnego ułatwiało ekspansję podczas glacjałów, lecz było przyczyną regresu jego zasięgu w interglacjałach (Środoń 1970).

W Karpatach i Sudetach Pleurospermum austriacum jest spotykany głównie w ziołoroślach klasy Betulo-Adenostyletea. Natomiast na Wyżynie Krakowsko-Częstochowskiej i Wyżynie Małopolskiej żebrowiec górski rośnie w fitocenozach leśnych ze związku Carpinion i Fageion, które rozwinęły się na żyznych siedliskach podczas sukcesji roślinności leśnej w Holocenie.

Pleurospermum austriacum jest rośliną monokarpiczną, która zakwita po kilku latach rozwoju i rozmnaża się wyłącznie generatywnie (MARKowski \& CHOJNACKi 1987). Dlatego wytwarzanie nasion ma kluczowe znaczenie dla trwania populacji. Tymczasem w 2018 r., u roślin znalezionych w paśmie Skał Kroczyckich, tylko niewielki procent kwiatów zawiązał owoce, natomiast w 2019 r. nie było roślin kwitnących. Według 


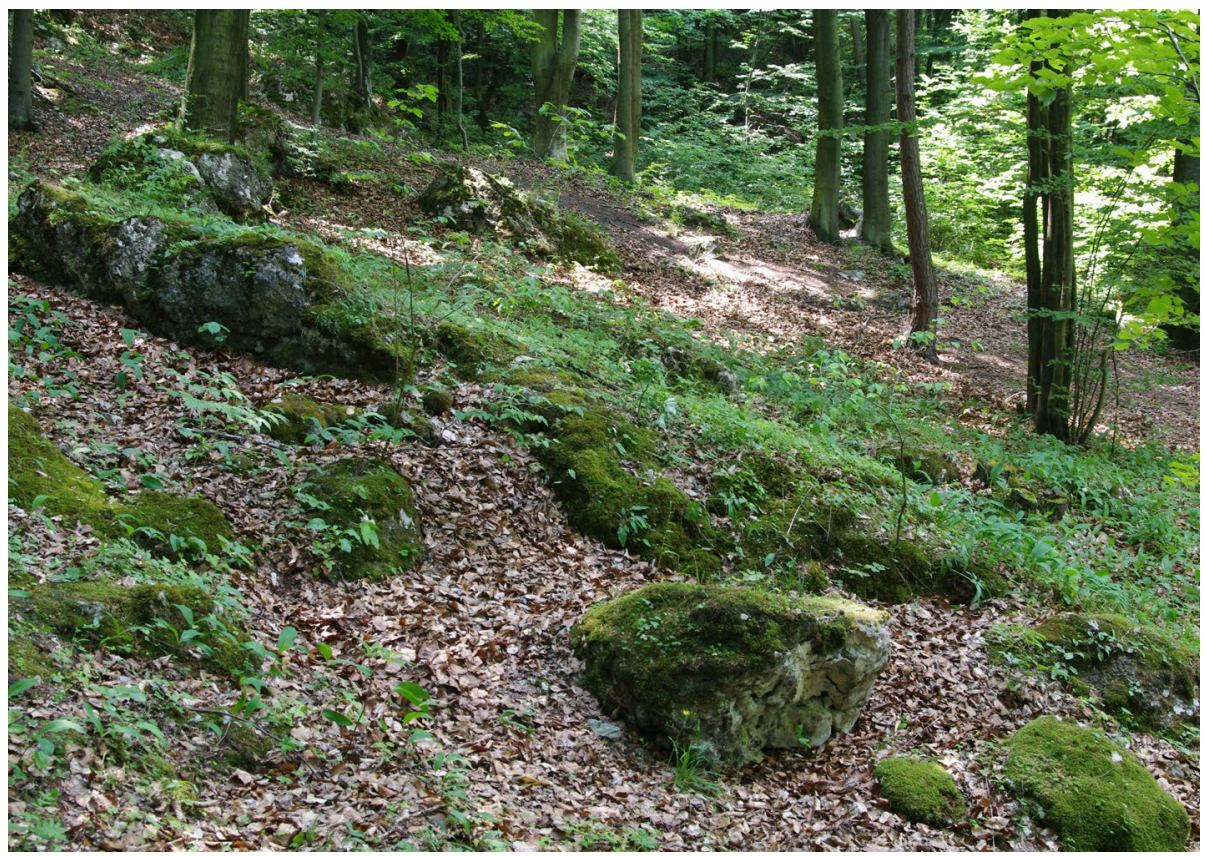

Ryc. 1. Siedlisko Pleurospermum austriacum w paśmie Skał Kroczyckich (fot. Z. Szeląg, 21.06.2019)

Fig. 1. Habitat of Pleurospermum austriacum in the Skały Kroczyckie hills (photo by Z. Szelagg, 21.06.2019)

IVERSEN'A (1954) owocowanie $P$. austriacum jest stymulowane przez niską temperaturę w poprzedzającym okresie spoczynku zimowego, choć hipoteza nie została zweryfikowana eksperymentalnie. Wzrost średniej rocznej temperatury powietrza, a zwłaszcza powtarzające się ciepłe zimy, są upatrywane jako główna przyczyna wymierania P. austriacum na Wyżynie Małopolskiej, gdzie nie odnaleziono ponad połowę znanych wcześniej stanowisk (Bróż i in. 2006). Obserwacja P. austriacum na Popielowej Górze pokazuje, że również niedostatek opadów w okresie kwitnienia ogranicza potencjał rozrodczy gatunku.

Ponieważ nowoodkryta populacja Pleurospermum austriacum jest niewielka, zebrany w celach dokumentacyjnych materiał zielnikowy (KRAM) składa się z liści osobników płonnych.

Summary. Pleurospermum austriacum (Apiaceae), a new mountain species in the flora of the Wyżyna Częstochowska Upland. In May 2018, Pleurospermum austriacum (L.) Hoffm. was found in the Skały Kroczyckie hills (Wyżyna Częstochowska Upland, S Poland; Fig. 1). The population consisted of 47 plants, including 11 flowering ones, growing in Dentario enneaphyllidis-Fagetum forest. In 2019 only 55 vegetative plants were observed in this locality, probably due to a prolonged spring drought. In Poland, P. austriacum occurs mainly in the Carpathians and Sudetes in tall-herb communities of the class Betulo-Adenostyletea; its occurrence outside mountainous areas consists of relict populations from the Pleistocene glacial (Vistulian). In the last fifty years, more than half of the previously known localities of P. austriacum in the Małopolska Upland and Wyżyna Krakowsko-Częstochowska Upland have disappeared. Climatic changes are considered the main threat to relict lowland populations of $P$. austriacum in Poland. 


\section{LITERATURA}

Bróż E., Podgórska M. \& PrZemyski A. 2006. The extinction of relict locations of Pleurospermum austriacum (L.) Hoffm. on the Małopolska Upland. - Nature Conservation 62(5): 43-57.

Celiński F., Rostański K., Sendek A., Wika S. \& CabaŁa S. 1978-1979. Nowe stanowiska rzadkich roślin naczyniowych na Górnym Śląsku i terenach przyległych. Cz. IV. - Zeszyty Przyrodnicze Opolskiego Towarzystwa Przyjaciół Nauk 18: 3-18.

IVERSEN J. 1954. The late-glacial flora of Denmark and its relation to climate and soil. - Danmarks Geologiske Undersøgelse, II Række 80: 87-119.

MAMAKowA K. \& ŚRODOŃ A. 1977. O pleniglacjalnej florze z Nowej Huty i osadach czwartorzędu doliny Wisły pod Krakowem. - Rocznik Polskiego Towarzystwa Geologicznego 46: 485-511.

Markowski R. \& ChoJnAcKi W. 1987. The biology of Pleurospermum austriacum (L.) Hoffm. in a relict locality of the Kashubian Lake District. - Acta Societatis Botanicorum Poloniae 56: 337-351.

Meusel H., Jäger E., Rauschert S. \& Weinert E. 1978. Vergleichende Chorologie der zentraleuropäischen Flora. 2, Text s. 418, Karten s. 171. Gustav Fischer Verlag, Jena.

MichaliK S. 1978. Rośliny naczyniowe Ojcowskiego Parku Narodowego. - Studia Naturae, Seria A 16: $1-171$.

RosTAFIŃSKI J. 1872. Florae Polonicae Prodromus. Uebersicht der bis jetzt im Königreiche Polen beobachteten Phanerogamen. - Verhandlungen der kaiserlich-königlichen zoologisch-botanischen Gesellschaft in Wien 22: 81-208.

SzAFER W. 1930. Element górski we florze niżu polskiego. - Rozprawy Wydziału Matematyczno-Przyrodniczego, Polska Akademia Umiejętności 69, Seria 3, Dział B: 83-196.

ŚRodoń A. 1970. Pleurospermum austriacum (L.) Hoffm. in the Quaternary of Poland. - Fragmenta Floristica et Geobotanica 16: 193-198.

ZAJAC M. 1996. Mountain vascular plants in the Polish Lowlands. - Polish Botanical Studies 11: 1-92.

ZAJĄC M. \& ZAJĄC A. 2009. Elementy geograficzne rodzimej flory Polski. s. 94. Pracownia Chorologii Komputerowej, Instytut Botaniki, Uniwersytet Jagielloński, Kraków.

ZBIGNIEw Szelą, Instytut Biologii, Uniwersytet Pedagogiczny w Krakowie, ul. Podchorażych 2, 30-084 Kraków, Polska; e-mail: azszelag@wp.pl

Wptynęto: 03.11.2019 r.; przyjęto do druku: 27.04.2020 r.

DOI: https://doi.org/10.35535/ffgp-2020-0048

\section{Występowanie Bupleurum rotundifolium (Apiaceae) na Wzgórzach Chęcińskich (Góry Świętokrzyskie)}

\footnotetext{
Bupleurum rotundifolium L. (przewiercień okragłolistny) jest jednym z najrzadszych archeofitów występujących w Polsce. Jego naturalny zasięg obejmuje południową Europę oraz południowo-zachodnią Azję. Ponadto rozprzestrzenił się na znacznych obszarach Europy (poza jej północnymi i północno-wschodnimi obszarami) na siedliskach segetalnych (Meusel i in. 1978; ZająC i in. 2009).
} 